University of Nebraska - Lincoln

DigitalCommons@University of Nebraska - Lincoln

\title{
Genotype Effects and Genotype by Environment Interactions for Traits of Elite Switchgrass Populations
}

\author{
Andrew A. Hopkins \\ Oklahoma State University \\ Kenneth P. Vogel \\ University of Nebraska-Lincoln, kvogel1@unl.edu \\ K. J. Moore \\ lowa State University \\ K. D. Johnson \\ Purdue University \\ I. T. Carlson \\ lowa State University
}

Follow this and additional works at: https://digitalcommons.unl.edu/usdaarsfacpub

Hopkins, Andrew A.; Vogel, Kenneth P.; Moore, K. J.; Johnson, K. D.; and Carlson, I. T., "Genotype Effects and Genotype by Environment Interactions for Traits of Elite Switchgrass Populations" (1995).

Publications from USDA-ARS / UNL Faculty. 1900.

https://digitalcommons.unl.edu/usdaarsfacpub/1900

This Article is brought to you for free and open access by the U.S. Department of Agriculture: Agricultural Research Service, Lincoln, Nebraska at DigitalCommons@University of Nebraska - Lincoln. It has been accepted for inclusion in Publications from USDA-ARS / UNL Faculty by an authorized administrator of DigitalCommons@University of Nebraska - Lincoln. 


\title{
Genotype Effects and Genotype by Environment Interactions for Traits of Elite Switchgrass Populations
}

\author{
Andrew A. Hopkins, K. P. Vogel,* K. J. Moore, K. D. Johnson, and I. T. Carlson
}

\begin{abstract}
Switchgrass (Panicum virgatum L.) is used as a forage species and has shown potential for use in production of fuel ethanol from cellulosic biomass. Objectives of this research were to determine performance differences between elite switch grass populations for agronomic, forage quality, and biofuel traits and to determine the magnitude of genotype $X$ environment $(G \times E)$ interactions for these traits across midwestern environments. Twenty elite switchgrass populations, consisting of cultivars and advanced breeding populations, were planted in sward trials at Mead, NE, Ames, IA, and West Lafayette, IN, during 1990 and were evaluated in 1991 and 1992 . Forage samples were taken at a vegetative growth stage, at heading, and at the end of the season. Plots were harvested for forage yield at heading and at the end of the growing season. Forage composition and in vitro dry matter digestibility was determined using near infrared reflectance spectroscopy. Significant differences $(P<0.05)$ between populations for forage yield were found at individual locations but not across locations, except at the $P=0.10$ probability level, because of $\mathrm{G} \times \mathrm{E}$ interactions. Genotype $X$ environment interactions were significant for hemicellulose plus cellulose (holocellulose) yield, a potentially important biofuel trait. In vitro dry matter digestibility was more stable than both forage yield and holocellulose yield. Despite large $G \times E$ interaction effects, a few populations consistently ranked high in forage yield and holocellulose yield. Multiple location, multiple year sward trials will be needed to develop switchgrasses broadly adapted to the midwest.
\end{abstract}

$S^{w}$ ITCHGRASS is a perennial warm season grass native to a large area of North America (Stubbendieck et al., 1992) and is used for forage production and conservation purposes. Research is currently underway to develop a system for production of fuel ethanol from cellulosic biomass (Lynd et al., 1991). If economically feasible, this system could provide an additional marketing outlet for forage. Cherney et al. (1990) in Indiana and Parrish et al. (1990) in Virginia evaluated potential biomass crops and concluded that switchgrass was one of the most promising. In biofuel production, hemicellulose and cellulose (holocellulose) could be enzymatically hydrolyzed to yield sugars, which in turn could be fermented into ethanol. As such, yield of holocellulose may be an important biomass trait. Breeding switchgrass for increased yield could be one way to improve the economic competitiveness of biomass-derived ethanol (Bransby et al., 1990)

A.A. Hopkins, Dep. of Agronomy, Oklahoma State University, Stillwater, OK 74078-0507; K.P. Vogel, USDA-ARS, 344 Keim Hall, Univ. of Nebraska, P.O. Box 830937, Lincoln, NE 68583-0937; K.J. Moore, Dep. of Agronomy, Iowa State Univ., Ames, IA 50011; K.D. Johnson, Dep. of Agronomy, Purdue Univ., West Lafayette, IN 47907-1150; and I.T. Carlson, Dep. of Agronomy, Iowa State Univ., Ames, IA 50011. The reported research is from a dissertation submitted by the senior author in partial fulfillment of the requirements for a Ph.D. degree at the Univ. of Nebraska. The research was funded in part by the U.S. Dep. of Energy's Biomass Fuels program via the Oak Ridge National Laboratory Contract no. DE-AI05-900R21954. Journal Series no. 10596, Nebraska Agric. Exp. Stn. Received 3 Feb. 1994. *Corresponding author.

Published in Crop Sci. 35:125-132 (1995).
In the north central states, most switchgrass cultivars in wide use, such as Pathfinder (Newell, 1968) and Trailblazer (Vogel et al., 1991), are based on germplasm originating from the Great Plains. An exception is 'Cavein-Rock', which originated from germplasm collected from southern Illinois and was developed by the USDASCSs Plant Material Center at Ellsberry, MO. Performance of Great Plains germplasm in midwest environments has not been adequately tested. Disease pressure may be greater under the humidity and rainfall conditions found in regions east of the Great Plains. In Pennsylvania, helminthosporium spot blotch incited by Helminthosporium sativum L. was more severe on 'Blackwell', a cultivar originating from Oklahoma, than on strains originating from eastern states such as New York (Zeiders, 1984). In Pennsylvania, Jung et al. (1985) reported that forage yield and digestibility of Blackwell was comparable with that of ecotypes originating from the eastern USA. At two locations near each other in Pennsylvania, Cave-in-Rock was consistently higher-yielding than both Blackwell and Pathfinder (Jung et al., 1988). Twidwell et al. (1988) reported that in Indiana, Cave-in-Rock had greater in vitro dry matter digestibility (IVDMD) than Trailblazer and Pathfinder.

To date, investigations of $\mathrm{G} \times \mathrm{E}$ interactions in switchgrass have been confined to genotype $\times$ year $(G \times$ $Y$ ) or genotype $\times$ growth stage $(G \times G S)$ interactions. Substantial $G \times Y$ interactions for seed and forage yield (Eberhart and Newell, 1959) and xylose concentration (Godshalk et al., 1988a) have been reported in switchgrass. However, Godshalk et al. (1986) found no significant $\mathrm{G} \times \mathrm{Y}$ interactions for forage yield, IVDMD, N concentration of initial growth, and IVDMD of regrowth. Twidwell et al. (1988) found no significant $G \times Y$ interactions for IVDMD and detergent fiber components among the cultivars Cave-in-Rock, Pathfinder, and Trailblazer; $G \times$ GS interactions were significant only for $\mathrm{N}$ concentration. Genotype $\times$ growth stage interactions for IVDMD were observed by Gabrielsen et al. (1990) among switchgrass populations divergently selected for digestibility but were considered minor.

Objectives of this research were to (i) determine genotypic differences between elite breeding populations of switchgrass for agronomic, forage quality, and biofuel traits; and (ii) determine the magnitude of $G \times E$ interactions for these traits across midwestern environments.

\section{MATERIALS AND METHODS}

Experimental switchgrass populations developed by the USDA-ARS grass breeding project at the University of Ne-

Abbreviations: ADF, acid detergent fiber; ADL, acid detergent lignin; $\mathrm{NDF}$, neutral detergent fiber; $\mathrm{G} \times \mathrm{E}$, genotype $\times$ environment; $\mathrm{G} \times$ $Y$, genotype $\times$ year; G $\times$ GS, genotype $\times$ growth stage; $P \times$ L, population $\times$ location; $P \times Y$, population $\times$ year; IVDMD, in vitro dry matter digestibility; NIRS, near infrared reflectance spectrophotometer; ANOVA, analysis of variance. 
braska and cultivars commercially available in the north central states were used in this research (Table 1).

The experiment was planted near Mead, NE, in a Sharpsburg silt loam (fine, montmorillonitic, mesic Typic Argiudoll) in 4.5 by $1.5 \mathrm{~m}$ plots on 31 May 1990 . Near Ames, IA, 3.7 by 0.9 m plots were planted on 30 May 1990 in a Webster silty clay loam (fine-loamy, mixed, mesic Typic Haplaquoll). Near West Lafayette, IN, 4.9 by $0.9 \mathrm{~m}$ plots were planted in a Chalmers silt loam (fine-silty, mixed, Mesic Typic Haplaquoll) on 18 May 1990. Plot drills were used to plant the trials; the seeding rate at all locations was 860 pure live seeds $\mathrm{m}^{-2}$. A randomized complete-block design with four replications was used at each location. Herbicide treatment at Mead and Ames consisted of $2.2 \mathrm{~kg}$ active ingredient (a.i.) $\mathrm{ha}^{-1}$ of atrazine [6-chloro-N-ethyl-N'-(1-methylethyl)-1,3,5-triazine-2,4-diamine]. At West Lafayette, $1.7 \mathrm{~kg}$ a.i. atrazine $\mathrm{ha}^{-1}$ was applied. Application was postplanting at all three locations.

Plots in Iowa and Indiana were sufficiently weed-free the year of establishment and had headed by the end of the season, so that collection of valid data on forage yield was possible. Weed growth was removed periodically with a flail plot harvester at Mead in 1990, so forage yield data were not collected. Plots were sampled for dry matter determinations after a killing frost on 16 October at Ames and 9 November at West Lafayette. Forage yields were harvested with a flail plot harvester with a harvest height of $10 \mathrm{~cm}$.

Residue was removed from plots at Mead in early spring 1991 by burning. Plots were sprayed with chlorsulfuron [2-Chloro-N-[[(4-methoxy-6-methyl-1,3,5-triazin-2-yl)-amino]carbonyl]benzenesulfonamide]] at $16.7 \mathrm{~g}$ a.i. ha ${ }^{-1}$ and metolachlor [2-chloro-N-(2-ethyl-6-methylphenyl)-N-(2-methoxy1-methylethyl)acetamide] at $2.2 \mathrm{~kg} \mathrm{a.i.} \mathrm{ha-1}{ }^{-1}$ prior to spring growth in 1991 at Mead and West Lafayette. Metolachlor (2.8 $\mathrm{kg} \mathrm{a.i.} \mathrm{ha}{ }^{-1}$ ) was applied on $17 \mathrm{Apr} .1991$ at Ames. Alachlor [2-chloro-2',6'-diethyl-N-(methoxymethyl)acetanilide], at 2.2 kg a.i. ha ${ }^{-1}$, and chlorsulfuron were applied on 1 May 1992 at Mead. Herbicides were not applied in 1992 to the trials at Ames or West Lafayette. Plots were fertilized prior to spring growth in 1991 and 1992 with $112 \mathrm{~kg} \mathrm{~N}^{-1}$ applied as ammonium nitrate. In late July 1991 at West Lafayette, P (21 $\mathrm{kg} \mathrm{ha}^{-1}$ ) and $\mathrm{K}\left(90 \mathrm{~kg} \mathrm{ha}^{-1}\right)$ were applied.

Forage samples were taken from plots at a vegetative growth stage and at heading. Plots were harvested at heading, and regrowth was sampled and harvested in the fall. Vegetative sampling took place in midJune at all locations in 1991 and 1992. Samples were taken at heading on 29 July 1991 and 1992 at Mead, on 17 July 1991 and 4 Aug. 1992 at Ames, and on 16 July 1991 and 11 Aug. 1992 at West Lafayette. Care was taken not to sample regrowth. Plots were harvested at heading on the same day as sampling except at Mead, where plots were harvested 31 July 1991 and 3 Aug. 1992. Regrowth sampling and harvest dates were 22 Oct. 1991 and 13 Oct. 1992 at Mead, 21 Nov. 1991 and 20 Oct. 1992 at Ames, and 26 Nov. 1991 and 21 Oct. 1992 at West Lafayette. Regrowth was harvested after a killing frost in 1991 but prior to complete senescence in 1992.

All forage samples were collected by cutting plants at $\approx 10$ $\mathrm{cm}$ height with hand sickles at random locations within a plot, except for regrowth at Mead and Ames in 1992 where samples were collected from the harvester. After drying at $50^{\circ} \mathrm{C}\left(60^{\circ} \mathrm{C}\right.$ at West Lafayette), forage samples were ground in a Wiley ${ }^{1}$ shear mill (Thomas Scientific, Swedesboro, NJ) to pass a 1-mm screen and reground to uniformity in a Udy cyclone impact mill (Udy Corporation, Fort Collins, CO). Sample grinding and analyses were completed at the USDA-ARS Forage Research Laboratory in Lincoln, NE.

At the time of the vegetative sampling, growth stage was determined using the system of Moore et al. (1991) on a number of tillers from random locations within a plot. The average stage of these tillers was taken as the growth stage of the plot. Growth stage data were also taken when plots were sampled at heading.

Heading date was visually determined as the date when half of the panicles in a plot had emerged from the flag leaf collar. Disease ratings were taken just prior to harvest, with $0 \%$ equaling no disease visible and $100 \%$ equaling canopy death due to disease. Dry matter concentrations, determined from samples taken just prior to harvests, were used to adjust corresponding plot forage yields to a dry weight basis. Dry weights of vegetative and heading stage samples were added to harvested yield at heading.

\footnotetext{
${ }^{1}$ Names of products are included for the benefit of the reader and do not imply endorsement by the USDA or the University of Nebraska.
}

Table 1. Origins of $\mathbf{2 0}$ switchgrass populations planted in seeded sward trials.

\begin{tabular}{|c|c|}
\hline Population & Origin \\
\hline Blackwell & $\begin{array}{l}\text { Northern Oklahoma upland type, developed by Soil Conservation Service Plant Materials Center (SCS PMC), } \\
\text { Manhattan, KS. }\end{array}$ \\
\hline Cave-in-rock & Lowland type from southern Illinois, developed by SCS PMC, Ellsberry, MO. \\
\hline Cave-in-rock high yield-DMD cycle $1 \dagger \ddagger$ & Developed by USDA Grass Breeding project, Lincoln, NE, using RRPS. $\$$ \\
\hline Ey $\times$ FF cycle 0 & Upland synthetic derived from Kansas and Nebraska collections by USDA Grass Breeding project, Lincoln, NE. \\
\hline Ey $\times$ FF low IVDMD cycle 1 & Selected from Ey $\times$ FF cycle 0 by USDA Grass Breeding project. \\
\hline Ey $\times$ FF high IVDMD cycle 3 & Developed by USDA Grass Breeding project, using RRPS. \\
\hline Ey $\times$ FF high IVDMD cycle 3 wS & $\begin{array}{l}\text { Synthetic population derived from winter survivors from a space planted Ey } \times \text { FF High IVDMD cycle } 3 \text { nursery } \\
\text { at Mead, NE. }\end{array}$ \\
\hline Ey $\times$ FF high yield cycle 3 & Developed by USDA Grass Breeding project, using RRPS. \\
\hline Kanlow & Lowland type from central Oklahoma, developed by SCS PMC, Manhattan, KS. \\
\hline Late synthetic high yield cycle 3 & Derived from an upland, late maturing synthetic by USDA Grass Breeding project, using RRPS. \\
\hline Late synthetic high yield-DMD cycle 2 & Derived from an upland, late-maturing synthetic by USDA Grass Breeding project, using RRPS. \\
\hline Nebraska 28 & Northern Nebraska upland type, developed by USDA Grass Breeding project. \\
\hline Pathfinder & Upland type from Kansas, Nebraska; similar in origin to Ey $\times$ FF cycle 0 . \\
\hline Pathfinder pasture clones & Synthetic derived by polycrossing clones from a Pathfinder pasture subjected to multiple years of grazing. \\
\hline Pathfinder seedling vigor cycle 3 & Developed by USDA Grass Breeding project, using RRPS. \\
\hline Pathfinder high yield cycle 3 & Developed by USDA Grass Breeding project, using RRPS. \\
\hline Pathfinder high yield-DMD cycle 2 & Developed by USDA Grass Breeding project, using RRPS. \\
\hline Sunburst & South Dakota upland type, developed at South Dakota State, Brookings, SD. \\
\hline Trailblazer & Selected from Ey $\times$ FF cycle 0 for one cycle of high IVDMD by USDA Grass Breeding project, using RRPS. \\
\hline Trailblazer p & Synthetic derived by polycrossing clones from a Trailblazer pasture subjected to multiple years of grazing. \\
\hline
\end{tabular}

† Identification system: base population - selection criteria - cycles of selection.

‡ DMD, IVDMD = in vitro dry matter digestibility.

$\$$ RRPS = recurrent, restricted phenotypic selection. 
Percentage stand was determined after harvest. A $1-\mathrm{m}^{2}$ grid, divided into 25 equally sized sub-squares, was randomly placed within a plot. Squares not containing a live switchgrass plant were counted. This was repeated in a second area within the same plot. The total number of squares without a live switchgrass plant was multiplied by two and the resulting number subtracted from 100 to give percentage stand.

Dry weight of regrowth samples were added to regrowth forage yields, except where samples were collected from the harvester.

\section{Forage Quality Analysis}

All samples were scanned using a near infrared reflectance spectrometer (NIRS; Technicon Infralyzer 500, Bran \& Luebbe Analyzing Technologies, Buffalo Grove, IL) across a wavelength range of 1100 to $2500 \mathrm{~nm}$ with 2-nm steps. As much as possible, wet lab data used in developing and verifying NIRS prediction equations were obtained from samples originating from different blocks, locations, sampling stages, and populations. Laboratory values were determined as follows. The procedure of Marten and Barnes (1980) was used to determine IVDMD; rumen fluid was collected and bulked from two cannulated steers (Bos taurus), one being maintained on a diet of alfalfa (Medicago sativa L.), the other on a diet of corn cobs (Zea mays L.). Neutral detergent fiber (NDF), acid detergent fiber (ADF), and acid detergent lignin (ADL) were determined using the sequential procedure of Van Soest and Robertson (1980). Hemicellulose was estimated as the difference between NDF and ADF, whereas cellulose was estimated as the difference between ADF and ADL. Holocellulose yield was determined as the product of percentage holocellulose (e.g., $700 \mathrm{~g} \mathrm{~kg}^{-1}=0.700$ ) times forage yield, for both heading and regrowth data. Lignin yield at heading was calculated in a similar manner.

Laboratory values obtained from the samples were used to develop NIRS prediction equations for IVDMD, NDF, ADF, and ADL by using stepwise regression. Complete details of prediction equation development and verification are given in Hopkins (1993). Except where noted, prediction and verification sample sets contained, in approximately equal numbers, samples originating from the present research and from Hopkins et al. (1995). A given prediction equation was developed using a sample set containing $\approx 7 \%$ of all samples to be predicted with that equation, except as follows. The 1991 NDF and ADL prediction equations were used for 1991 and 1992 samples. The 1992 ADF prediction equation was developed using a set of samples from 1991. Prediction equations for IVDMD and NDF of 1992 regrowth were developed using samples from both years (more than 160 total). In all cases, a given prediction equation was verified (Table 2) with a sample set containing $\approx 3 \%$ of all samples to be predicted with that equation. Samples used for verification were not used in developing prediction equations. The 1992 verification set for regrowth constituents contained samples from the present research alone.

\section{Statistical Analysis}

\section{Agronomic Data}

Location-year data were analyzed as a randomized complete-block design. Blocks were assumed to be random effects; populations were fixed effects. When included in the analyses of variance (ANOVA) model, years and locations were assumed to be random effects. Data from individual locations were analyzed across years as a split plot in time with popula-
Table 2. Bias, standard error of prediction (SEp) and multiple correlation coefficient $\left(\boldsymbol{R}^{2}\right)$ for near infrared reflectance spectroscopy prediction equations.

\begin{tabular}{|c|c|c|c|c|c|c|}
\hline \multirow[b]{2}{*}{ Constituent $\dagger$} & \multicolumn{3}{|c|}{1991} & \multicolumn{3}{|c|}{1992} \\
\hline & Bias $\ddagger$ & SEp & $R^{2}$ & Bias & SEp & $R^{2}$ \\
\hline & & & $-\mathbf{g}$ & & & \\
\hline \multirow{6}{*}{$\begin{array}{l}\text { IVDMD } \\
\text { NDF } \\
\text { ADF } \\
\text { ADL } \\
\text { IVDMD (regrowth) } \\
\text { NDF (regrowth) }\end{array}$} & 3.8 & 26.9 & 0.98 & -4.6 & 28.0 & \\
\hline & 2.0 & 18.0 & 0.8 & 9.9 & 19.7 & \\
\hline & 1.0 & 15.0 & 0.9 & -10.9 & 22.9 & \\
\hline & -2.4 & 7.0 & 0.94 & -2.1 & 6.4 & 0.9 \\
\hline & & & & -64.0 & 23.0 & \\
\hline & & & & 26.0 & 18.0 & \\
\hline
\end{tabular}

$\dagger$ IVDMD = in vitro dry matter digestibility, $\mathrm{NDF}=$ neutral detergent fiber, ADF = acid detergent fiber, $A D L=$ acid detergent Iignin.

¥ For a given constituent, bias is the average difference between predicted values and wet lab values.

tions as whole plots and years as split plots. A nested factorial analysis (Hicks, 1973) was used for data across locations from individual years, with blocks nested within locations. Data were analyzed across years and locations in a similar manner. Linear contrasts were used when comparing specific pairs of populations. The method of Neter et al. (1985) was used to calculate approximate $F$ values, where needed, with approximate degrees of freedom calculated according to Satterthwaite (1946). Expected mean squares and all individual ANOVAs are listed in Hopkins (1993).

\section{Forage Quality Maturity Adjustment}

In the present experiment, differences in growth stage between populations at a given sampling were expected. To reduce confounding of genotype and $\mathrm{G} \times \mathrm{E}$ interaction effects with maturity, forage quality data were analyzed at a uniform growth stage as follows. With data from both 1991 and 1992, a regression coefficient for digestibility at the vegetative sampling was determined by linearly regressing IVDMD against growth stage. Digestibility data were adjusted when the regression coefficient for maturity was significant and the coefficient of determination $\left(R^{2}\right)$ was $\geq 0.30$ (Table 3 ). Individual plot data were adjusted to a uniform growth stage, $\mathrm{E}_{3}$, using the following formula:

$$
\text { Adjusted IVDMD = IVDMD + }(b \times(x-2.65))
$$

where IVDMD is unadjusted digestibility value, $b$ is maturity coefficient for IVDMD, and $x$ is observed plot stage. The growth stage $E_{3}$, coded as 2.65 according to Moore et al. (1991), was near the overall mean for vegetative growth stage and occurred just prior to the boot stage. Vegetative data for hemicellulose, cellulose, and ADL were also adjusted to a uniform growth stage using the same procedures. Data for forage quality at heading were not adjusted because of low $R^{2}$ values.

Table 3. Regression coefficients $(b) \pm$ standard error, used in adjusting data to a uniform vegetative growth stage, and coefficients of determination $\left(R^{2}\right)$ for forage quality-growth stage regression models.

\begin{tabular}{lcc}
\hline Constituent $\dagger$ & $b \ddagger$ & $R^{2}$ \\
\hline IVDMD & $-247 \pm 13$ & 0.42 \\
Hemicellulose & $-82 \pm 6$ & 0.30 \\
Cellulose & $76 \pm 6$ & 0.31 \\
ADL & $43 \pm 3$ & 0.36 \\
\hline
\end{tabular}

† IVDMD $=$ in vitro dry matter digestibility, ADL $=$ acid detergent lignin. $\ddagger \mathbf{b}=\mathrm{g} \mathrm{kg}^{-1}$ change in constituent per unit change in growth stage. 
Table 4. Analysis of variance with mean squares for agronomic and forage quality traits of 20 elite switchgrass populations.

\begin{tabular}{|c|c|c|c|c|c|c|c|c|}
\hline \multirow[b]{2}{*}{ Source } & \multirow[b]{2}{*}{ df } & \multirow[b]{2}{*}{ Disease } & \multirow[b]{2}{*}{ Stand } & \multicolumn{2}{|c|}{ Forage yield } & \multicolumn{3}{|c|}{ IVDMD† } \\
\hline & & & & Heading & Regrowth & Vegetative & Heading & Regrowth \\
\hline & & \multicolumn{2}{|c|}{$\longrightarrow \%^{2} \longrightarrow$} & \multicolumn{2}{|c|}{$\mathrm{kg} \mathrm{ha}^{-2}$} & 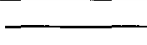 & $\mathbf{g ~ k g}^{-2}$ & \\
\hline Location & 2 & 187 & 3358* & $205366118^{*}$ & 56308922 & 13273 & 5777 & 36420 \\
\hline Block (L) & 9 & 168 & $46^{*}$ & 4317258 & 1171254 & 97 & 162 & 162 \\
\hline Population $\ddagger$ & 19 & 115 & $606^{*}$ & 29954614 & $1971899^{*}$ & $700^{*}$ & $1161^{*}$ & 354 \\
\hline $\mathbf{P} \times \mathbf{L}$ & 37 & 59 & 22 & $8587666^{*}$ & 260177 & 138 & 199* & 209* \\
\hline $\mathbf{P} \times \mathbf{B}(\mathrm{L})$ & 168 & 26 & $17 *$ & $1980304^{*}$ & $102340^{*}$ & 93 & 54 & 47 \\
\hline Year & 1 & 7475 & 192 & 27738508 & 35690102 & $26093^{*}$ & 14992 & 519070 \\
\hline $\mathbf{Y} \times \mathbf{L}$ & 2 & $1502 *$ & 21 & 4878867 & $6599280^{*}$ & 327 & $7849^{*}$ & 72 191* \\
\hline $\mathbf{Y} \times \mathbf{B}(\mathrm{L})$ & 9 & $106^{*}$ & 3 & $2480589 *$ & $718641^{*}$ & 205 & 115 & 97 \\
\hline $\mathbf{P} \times \mathbf{Y}$ & 19 & 76 & $57^{*}$ & $9895163^{*}$ & 171911 & 228 & 101 & 238* \\
\hline $\mathbf{P} \times \mathbf{L} \times \mathbf{Y}$ & 37 & $52^{*}$ & 10 & 1091244 & $169757^{*}$ & 133 & 96 & 99* \\
\hline $\mathbf{P} \times \mathbf{Y} \times \mathbf{B}(\mathrm{L})$ & 168 & 25 & 4 & 756357 & 63756 & 128 & 66 & 57 \\
\hline
\end{tabular}

* Significant $(P<0.05)$.

$\uparrow$ IVDMD $=$ in vitro dry matter digestibility.

$\ddagger$ Population df slightly less than 19 due to failure of Kanlow to establish at Mead.

\section{Forage Quality Data}

Analyses of forage quality data were the same as outlined for agronomic data, except that growth stage was considered a fixed effect when included in the model. Location-year data were analyzed across growth stages as a split plot in time with populations as whole plots, growth stages as split plots. Because of consistent $\mathrm{G} \times \mathrm{GS}$ interactions, forage quality data were subsequently analyzed by growth stage. All data were analyzed using the SAS software package (SAS Institute, 1990).

\section{RESULTS AND DISCUSSION Agronomic Data}

In the year of establishment, entries differed $(P<$ 0.05 ) for forage yield across locations (data not shown) whereas the population $\times$ location $(P \times L)$ interaction was nonsignificant $(P>0.05)$. Mean forage yields ranged

Table 5. Means across 2 yr of the top ranking populations, mean ranges, population mean squares (MSp), and population by year mean squares (MSpy) for yield at heading of 20 elite switchgrass populations grown at three locations.

\begin{tabular}{|c|c|c|c|}
\hline cation and population & Yield & MSp & MSpy \\
\hline & $\mathbf{k g ~ h a} \mathbf{a}^{-1}$ & $\ldots$ kg h & $\mathbf{a}^{-2}$ \\
\hline $\begin{array}{l}\text { Mead } \\
\text { Late syn high yield C3 } \\
\text { Late syn high yield-DMD C2 } \\
\text { Sunburst } \\
\text { Pathfinder high yield-DMD C2 } \\
\text { Cave-in-rock } \\
\text { Total range } \\
\text { SE† }\end{array}$ & $\begin{array}{r}14380 \\
13310 \\
13300 \\
13230 \\
12960 \\
3520 \\
720\end{array}$ & 4715563 & 3017972 * \\
\hline $\begin{array}{l}\text { Ames } \\
\text { Cave-in-rock } \\
\text { Cave-in-rock high yield-DMD C1 } \\
\text { Late syn high yield C3 } \\
\text { Blackwell } \\
\text { Sunburst } \\
\text { Total range } \\
\text { SE }\end{array}$ & $\begin{array}{r}14280 \\
13480 \\
11200 \\
11150 \\
11020 \\
9820 \\
850\end{array}$ & $29493607^{*}$ & $4499899 *$ \\
\hline $\begin{array}{l}\text { West Lafayette } \\
\text { Cave-in-rock high yield-DMD C1 } \\
\text { Cave-in-rock } \\
\text { Trailblazer } \\
\text { Ey } \times \text { FF high yield C3 } \\
\text { Ey } \times \text { FF low IVDMD cycle } 1 \\
\text { Total range } \\
\text { SE }\end{array}$ & $\begin{array}{r}14890 \\
14360 \\
13390 \\
13180 \\
13000 \\
5010 \\
850\end{array}$ & $12791748^{*}$ & $95764^{*}$ \\
\hline
\end{tabular}

* Significant $(P<0.05)$.

$+\mathrm{SE}=$ standard error. from $3150 \mathrm{~kg} \mathrm{ha}^{-1}$ for NE 28 up to $5600 \mathrm{~kg} \mathrm{ha}^{-1}$ for the Trailblazer Pasture Clones population.

Populations that had the greatest yields in the establishment year were not necessarily the most productive strains in subsequent years. Rank correlations between mean forage yields in the establishment year and mean forage yields in subsequent years were nonsignificant $(P>0.05)$ except between 1990 and 1991 mean yields at West Lafayette. Even then, this correlation $(r=0.55)$ was not strong. Forage yield in the year of establishment is important but less so than productivity in subsequent years because switchgrass is a long lived perennial.

Significant $(P<0.05) \mathrm{P} \times \mathrm{L}$ and population $\times$ year $(P \times Y)$ interactions (Table 4) occurred when nonestablishment year data were analyzed across locations and years. Differences between populations for forage yield at heading were not significant at the 0.05 level but were significant at the 0.10 level $(P \approx 0.07)$. Differences between populations for forage yield at heading were significant across years at Ames and West Lafayette (Table 5), as were $\mathrm{P} \times \mathrm{Y}$ interactions.

Significant $G \times E$ interactions for forage yield at heading were probably influenced by differing weather conditions in 1991 and 1992 (Table 6). July 1992 was particularly wet, with more than $18 \mathrm{~cm}$ of rain at Mead and more than $25 \mathrm{~cm}$ at both Ames and West Lafayette, whereas temperatures were below normal $(-1.4$ to

Table 6. Climatic data, with deviations from normal, for the 1991 and 1992 growing seasons at Mead, NE, Ames, IA, and West Lafayette, IN.

\begin{tabular}{|c|c|c|c|c|}
\hline \multirow[b]{2}{*}{ Location } & \multicolumn{2}{|c|}{$\begin{array}{c}\text { Seasonal } \\
\text { precipitation } \dagger\end{array}$} & \multicolumn{2}{|c|}{ Monthly temperature $\dagger$} \\
\hline & Total & Deviation & Average & Deviation \\
\hline & \multicolumn{2}{|c|}{$-\mathrm{cm}=$} & \multicolumn{2}{|c|}{$-{ }^{\circ} \mathrm{C}$} \\
\hline & & $\underline{1991}$ & & \\
\hline $\begin{array}{l}\text { Mead } \ddagger \\
\text { Ames }\end{array}$ & $\begin{array}{l}58.9 \\
75.3\end{array}$ & $\begin{array}{r}-9.3 \\
9.9\end{array}$ & $\begin{array}{l}18.9 \\
18.0\end{array}$ & $\begin{array}{l}0.3 \\
0.7\end{array}$ \\
\hline \multirow[t]{2}{*}{ West Lafayette } & 51.4 & -13.9 & 19.1 & 1.5 \\
\hline & & 1992 & & \\
\hline Mead & 42.0 & $\overline{-20.0}$ & 17.5 & -2.2 \\
\hline Ames & 55.9 & -3.6 & 17.0 & -1.4 \\
\hline West Lafayette & 63.4 & 4.6 & 16.9 & -1.5 \\
\hline
\end{tabular}

† Growing seasons were April-October, 1991, and April-September, 1992. ¥ Nearest reporting stations with complete precipitation (Wahoo, NE) and temperature (Ashland, NE) data used for Mead. 
$-2.2^{\circ} \mathrm{C}$ ) throughout the season. Forage yields were comparable between years for most populations (data not shown). However, Cave-in-Rock and Cave-in-Rock High Yield-DMD Cycle 1 produced greater forage yields in 1992 , about a $3000 \mathrm{~kg} \mathrm{ha}^{-1}$ increase averaged across locations, apparently in response to better growing conditions. Cave-in-Rock was also the only population ranking consistently among the top five populations for forage yield at heading at each location (Table 5). The fact that plots were burned in 1991 only at Mead may have had a minor influence on the $\mathrm{P} \times \mathrm{L}$ interaction that year.

Earlier research has demonstrated that selection for high IVDMD in switchgrass does not necessarily involve a sacrifice in forage yield (Vogel et al., 1984; Hopkins et al., 1993). In the present study, when data were analyzed across years and locations, Ey $\times$ FF Cycle 0 produced significantly $(P<0.05)$ greater forage yield at heading than did Ey $\times$ FF High IVDMD Cycle 3 . Forage yield of Ey $\times$ FF Cycle 0 exceeded forage yield of Ey $\times$ FF High IVDMD Cycle 3 at each location every year, the difference being greater than $2550 \mathrm{~kg} \mathrm{ha}^{-1}$ at West Lafayette in 1992.

Significant differences between populations for regrowth forage yield were detected along with a significant $\mathrm{P} \times \mathrm{L} \times \mathrm{Y}$ interaction (Table 4). Average regrowth forage yields were small relative to forage yield at heading, ranging from $890 \mathrm{~kg} \mathrm{ha}^{-1}$ (NE 28) up to $2670 \mathrm{~kg}$ $\mathrm{ha}^{-1}$ (Cave-in-Rock) in 1991 and from $740 \mathrm{~kg} \mathrm{ha}^{-1}$ (NE 28) up to $1780 \mathrm{~kg} \mathrm{ha}^{-1}$ (Kanlow) in 1992 . Regrowth forage yields were greater in 1991 due to warmer temperatures and a longer growth period after harvest of initial growth.

Disease ratings did not significantly differ between populations, although a significant $\mathrm{P} \times \mathrm{L} \times \mathrm{Y}$ interaction was found (Table 4). Stem rust, incited by Puccinia graminis L., was the prominent disease. Anthracnose, incited by Colletotrichum graminicola L., was present at West Lafayette in 1992. Mean disease ratings averaged across years were low, ranging at Mead, for example, from 5\% (Cave-in-Rock High Yield-DMD C1) to $20 \%$ ('Sunburst'). Also, the correlation between disease rating and forage yield was low $(r=-0.07)$ and nonsignificant $(P>0.05)$. Thus, foliar diseases probably had little or no effect on switchgrass production in this research.

Averaged across locations, full stands $(>90 \%)$ were present for all populations except Kanlow. Kanlow was excluded from analysis of agronomic data collected at Mead because of poor establishment. Significant differences among populations for stand percentage (Table 4) were due to the poor stands obtained with Kanlow. Therefore, except for Kanlow, differences in forage yield were not due to differences in establishment or persistence. At West Lafayette, Kanlow produced $14650 \mathrm{~kg}$ $\mathrm{ha}^{-1}$ in 1992 with an $83 \%$ stand compared with 9900 $\mathrm{kg} \mathrm{ha}^{-1}$ in 1991 with a $66 \%$ stand.

Heading date differed significantly between populations $(P<0.05)$. Heading dates, averaged across years and locations, ranged from early July for Sunburst and NE 28 to early August for Kanlow. Compared with 1991, heading date was delayed about $15 \mathrm{~d}$ in 1992 due to cooler $\left(-1.4\right.$ to $\left.-2.2^{\circ} \mathrm{C}\right)$ temperatures. This trait was not associated with yield as evidenced by a nonsignificant correlation between heading date and yield $(r=-0.07)$.

\section{Biofuel Traits}

Plots were harvested and forage sampled at heading or the $\mathrm{R}_{3}$ stage of maturity (Moore et al., 1991). At this growth stage, switchgrass produces large yields and would probably be harvested for biomass fuel feedstock.

Factors affecting biofuel production from switchgrass are unknown. However, holocellulose would be the primary source of fermentable sugars in ethanol production from biomass. Consequently, yield of holocellulose was considered the most important biofuel trait. Lignin could be a substantial, perhaps undesirable, by-product of biofuel production. As a result, lignin yield was also determined.

Across years and locations, significant $\mathrm{P} \times \mathrm{Y}$ and $\mathrm{P} \times \mathrm{L}$ interactions occurred for holocellulose yield at heading and lignin yield at heading (Table 7). Differences among populations for lignin yield were significant at the 0.10 but not the 0.05 levels of probability. Results were similar for holocellulose yield $(P \approx 0.11)$. Significant differences among populations at Ames and West Lafayette, and significant $P \times Y$ interactions at each location, occurred for holocellulose yield at heading (Table 8). No population ranked consistently among the top five at all locations for this trait. Still, large holocellulose yields were produced by most populations, as indicated by the narrow range at Mead and West Lafayette (Table 8). At Ames, much of the range can be attributed to 'Kanlow', which produced almost 50\% less holocellulose $\left(3170 \mathrm{~kg} \mathrm{ha}^{-1}\right)$ compared with Ey $\times$ FF High IVDMD Cycle $3\left(5990 \mathrm{~kg} \mathrm{ha}^{-1}\right)$, the second lowest ranking population. At heading, lignin yields averaged $730 \mathrm{~kg} \mathrm{ha}^{-1}$ at Mead, $640 \mathrm{~kg} \mathrm{ha}^{-1}$ at Ames, and $770 \mathrm{~kg} \mathrm{ha}^{-1}$ at West Lafayette.

The majority of switchgrass herbage was composed of holocellulose, with an average concentration of $\approx 700 \mathrm{~g}$ $\mathrm{kg}^{-1}$ at each location. Thus, selection for forage yield at heading, if successful, will probably increase holocellulose yield at heading. Increased forage yield at heading would also result in increased lignin yield at heading,

Table 7. Analysis of variance with mean squares for lignin yield and holocellulose yield of 20 elite switchgrass populations grown at three locations for $2 \mathrm{yr}$.

\begin{tabular}{|c|c|c|c|c|}
\hline \multirow[b]{2}{*}{ Source } & \multirow[b]{2}{*}{ df } & \multirow{2}{*}{$\begin{array}{c}\begin{array}{c}\text { Lignin } \\
\text { yield }\end{array} \\
\text { Heading }\end{array}$} & \multicolumn{2}{|c|}{ Holocellulose yield } \\
\hline & & & Heading & Fall regrowth \\
\hline & & & $-\mathbf{k g ~ h a} \mathbf{a}^{-2}$ & \\
\hline Location & 2 & 662801 & $85997790^{*}$ & 25077598 \\
\hline Block(L) & 9 & 33540 & 2096375 & 361855 \\
\hline Population $\dagger$ & 19 & 148894 & 13428368 & $787791 *$ \\
\hline $\mathbf{P} \times \mathbf{L}$ & 37 & $44463^{*}$ & $4155703^{*}$ & 111219 \\
\hline$P \times B(L)$ & 168 & $11133^{*}$ & $969397^{*}$ & $48520^{*}$ \\
\hline Year & 1 & 1927930 & 22339206 & 25005011 \\
\hline $\mathbf{Y} \times \mathbf{L}$ & 2 & $247021 *$ & 2641874 & $3693565^{*}$ \\
\hline $\mathrm{Y} \times \mathrm{B}(\mathrm{L})$ & 9 & $21591 *$ & $1183 \mathrm{CO3}^{*}$ & $217263^{*}$ \\
\hline $\mathbf{P} \times \mathbf{Y}$ & 19 & $53699 *$ & $4843801^{*}$ & 110083 \\
\hline $\mathbf{P} \times \mathbf{L} \times \mathbf{Y}$ & 37 & 8995 & 508406 & $81481^{\circ}$ \\
\hline $\mathbf{P} \times \mathbf{Y} \times \mathbf{B}(\mathbf{L})$ & 164 & 6768 & 358965 & 31872 \\
\hline
\end{tabular}

- Significant $(P<0.05)$

$\dagger$ Population df less than 19 due to failure of Kanlow to establish at Mead. 
Table 8. Means across $2 \mathrm{yr}$ for the top five ranking populations, mean ranges, population mean squares (MSp), and population by year mean squares (MSpy) for holocellulose yield at heading of 20 elite switchgrass strains grown at three locations.

\begin{tabular}{|c|c|c|c|}
\hline Location and population & $\begin{array}{c}\text { Holocellulose } \\
\text { yield }\end{array}$ & MSp & MSpy \\
\hline & $\mathrm{kg} \mathrm{ha}^{-1}$ & kg h & $\mathrm{ha}^{-2}$ \\
\hline \multicolumn{4}{|l|}{ Mead } \\
\hline Late syn high yield cycle 3 & 9990 & 2320030 & $1538441^{*}$ \\
\hline Sunburst & 9320 & & \\
\hline Late syn high yield-DMD C2 & 9210 & & \\
\hline Pathfinder high yield-DMD C2 & 9170 & & \\
\hline Trailblazer pasture clones & 8940 & & \\
\hline Total range & 1980 & & \\
\hline $\mathrm{SE} \dagger$ & 510 & & \\
\hline \multicolumn{4}{|l|}{ Ames } \\
\hline Cave-in-rock & 9890 & $13799794^{*}$ & $2152412^{*}$ \\
\hline Cave-in-rock high yield-DMD C1 & 9320 & & \\
\hline $\begin{array}{l}\text { Late syn high yield C3 } \\
\text { Blackwell }\end{array}$ & $\begin{array}{l}7920 \\
7860\end{array}$ & & \\
\hline $\begin{array}{l}\text { Blackwell } \\
\text { Sunburst }\end{array}$ & $\begin{array}{l}7860 \\
7800\end{array}$ & & \\
\hline $\begin{array}{l}\text { Sunburst } \\
\text { Total range }\end{array}$ & 6730 & & \\
\hline SE & 590 & & \\
\hline \multicolumn{4}{|l|}{ West Lafayette } \\
\hline Cave-in-rock high yield-DMD C1 & 10210 & $5559689 *$ & $2219784^{*}$ \\
\hline Cave-i & 9830 & & \\
\hline Trailblazer & 9380 & & \\
\hline Ey $\times$ FF low IVDMD cycle 1 & 9190 & & \\
\hline Ey $\times$ FF high yield cycle 3 & 9160 & & \\
\hline Total range & 3190 & & \\
\hline SE & 590 & & \\
\hline
\end{tabular}

* Significant $(P<0.05)$

$\dagger \mathrm{SE}=$ standard error.

unless a substantial decrease in lignin concentration occurred. Forage yield can be increased through selection in switchgrass populations (Godshalk et al., 1988b) but only when adequate genetic variation is present (Hopkins et al., 1993).

Populations differed significantly for holocellulose yield of regrowth (Table 7). Also, $\mathrm{P} \times \mathrm{L}$ and $\mathrm{P} \times \mathrm{Y}$ interactions were not significant for holocellulose yield of regrowth. Means averaged across years and locations for this trait were small, ranging from $550 \mathrm{~kg} \mathrm{ha}^{-1}$ for NE 28 up to $1480 \mathrm{~kg} \mathrm{ha}^{-1}$ for Cave-in-Rock. The potential of switchgrass as a biomass feedstock will depend on yield, production costs, and delivered price. Our results indicate that when harvested at heading, regrowth yields of switchgrass may be inadequate in some years to warrant harvesting.

\section{Forage Quality Data}

Forage quality data were analyzed by growth stage because of significant $(P<0.05)$ and consistent population $\times$ growth stage interactions (data not shown). The vegetative growth stages are typical of the maturity at which switchgrass is grazed. Sampling for forage quality at heading occurred at a growth stage when switchgrass is often harvested for hay. At such an advanced maturity, digestibility of switchgrass hay can become low and is primarily used for maintaining breeding herds.

As mentioned previously, digestibility values were adjusted to a uniform vegetative growth stage. Digestibility was significantly different between populations when sampled during vegetative growth, with no significant $\mathrm{G} \times \mathrm{E}$ interactions (Table 4). Significant $(P<0.05)$ $\mathrm{P} \times \mathrm{Y}$ interactions occurred for NDF, hemicellulose, and cellulose (data not shown). Among vegetative forage quality traits, IVDMD was significantly and most strongly associated with lignin $(r=-0.82)$.

Digestibility ranged from $605 \mathrm{~g} \mathrm{~kg}^{-1}$ for Cave-in-Rock to $548 \mathrm{~g} \mathrm{~kg}^{-1}$ for Ey $\times$ FF Low IVDMD Cycle 1 , averaged across locations and years. Cave-in-Rock and Ey $\times$ FF High Cycle 3 WS were among the top five populations, at each location, for vegetative IVDMD (Table 9).

The later heading date of Cave-in-Rock High Yield-

Table 9. Means across 2 years of the top ranking populations and mean ranges for in vitro dry matter digestibility IVDMD, adjusted to a uniform vegetative growth stage and at heading, of 20 elite switchgrass populations grown at three locations.

\begin{tabular}{|c|c|c|c|}
\hline Location and population & $\begin{array}{l}\text { Vegetative } \\
\text { IVDMD }\end{array}$ & Population & $\begin{array}{c}\begin{array}{c}\text { IVDMD at } \\
\text { heading }\end{array} \\
\end{array}$ \\
\hline & $\mathrm{g} \mathrm{kg}^{-1}$ & & $\mathrm{~g} \mathrm{~kg}^{-1}$ \\
\hline \multicolumn{4}{|l|}{ Mead } \\
\hline Cave-in-rock & 650 & Ey $\times$ FF high IVDMD cycle 3 wS & 492 \\
\hline Ey $\times$ FF high IVDMD cycle 3 WS & 625 & Ey $\times$ FF high IVDMD cycle 3 & 491 \\
\hline Cave-in-rock high yield-DMD C1 & 625 & Trailblazer pasture clones & 477 \\
\hline Ey $\times$ FF high IVDMD cycle 3 & 620 & Late syn high yield-DMD C2 & 460 \\
\hline Pathfinder high yield-DMD C2 & 619 & Pathfinder high yield C3 & 456 \\
\hline Total range & 71 & Total range & 106 \\
\hline SE & 16 & SE & 11 \\
\hline \multicolumn{4}{|l|}{ Ames } \\
\hline Kanlow & 612 & Kanlow & 498 \\
\hline Pathfinder high yield-DMD C2 & 609 & Ey $\times$ FF high IVDMD cycle 3 & 491 \\
\hline NE 28 & 609 & Ey $\times$ FF high IVDMD cycle 3 WS & 454 \\
\hline Cave-in-rock & 595 & Pathfinder high yield-DMD C2 & 452 \\
\hline Ey $\times$ FF high IVDMD cycle 3 WS & 594 & Trailblazer pasture clones & 448 \\
\hline Total range & 66 & Total range & 112 \\
\hline SE & 3 & SE & 15 \\
\hline \multicolumn{4}{|l|}{ West Lafayette } \\
\hline Cave-in-rock high yield-DMD C1 & 589 & Cave-in-rock high yield-DMD C1 & 456 \\
\hline Ey $\times$ FF high IVDMD cycle 3 WS & 579 & Cave-in-rock & 452 \\
\hline Pathfinder & 575 & Ey $\times$ FF high IVDMD cycle 3 & 438 \\
\hline Pathfinder seedling vigor C3 & 568 & Ey $\times$ FF high IVDMD cycle 3 WS & 435 \\
\hline Cave-in-rock & 566 & Trailblazer pasture clones & 425 \\
\hline Total range & 78 & Total range & 93 \\
\hline SE & 16 & SE & 5 \\
\hline
\end{tabular}


DMD Cycle 1 compared with Cave-in-Rock, averaging $<3 \mathrm{~d}$ at each location, is not sufficiently large to cause problems from a forage management perspective. Hence, unadjusted vegetative digestibility of these two populations was examined. Analyzed across years and locations, Cave-in-Rock High Yield-DMD Cycle 1 was significantly $(P<0.05)$ greater in unadjusted vegetative IVDMD than Cave-in-Rock. This difference was $\approx 13 \mathrm{~g}$ $\mathrm{kg}^{-1}$ when averaged across years and locations. Thus, selection for IVDMD in Cave-in-Rock was effective and is associated with later flowering.

Across years and locations, a significant $P \times L$ interaction for digestibility at heading was detected along with significant differences between populations (Table 4). Absence of a $\mathrm{P} \times \mathrm{Y}$ interaction indicates that populations ranked consistently across years for IVDMD at heading. A few strains had consistently high IVDMD at heading. Trailblazer Pasture Clones, Ey $\times$ FF High IVDMD C3 and its derivative, Ey $\times$ FF High IVDMD C3 WS, ranked among the top five populations at each location for IVDMD at heading (Table 9). These three ecotypes consistently had higher IVDMD than Ey $\times$ FF Cycle 0 , from which they originated. At heading, less lignin (ADL) was closely associated with greater IVDMD $(r=$ -0.85 ). Forage yield at heading had almost no association with IVDMD at heading $(r=-0.15)$. At heading, significant differences occurred between populations for $\mathrm{ADL}$ and holocellulose, along with significant $\mathrm{P} \times \mathrm{L}$ $X Y$ interactions (data not shown). For ADL, the $P \times$ $\mathrm{L}$ interaction was significant also. This research demonstrates that specific switchgrass populations, in seeded stands, can have consistently high IVDMD at heading across the midwest. However, the presence of $\mathrm{P} \times \mathrm{L}$ interactions indicates the importance of multiple location testing.

All $G \times E$ interactions were significant for IVDMD of regrowth (Table 4). Significant differences among populations for this trait were not detected. Average regrowth IVDMD in $1991\left(310 \mathrm{~g} \mathrm{~kg}^{-1}\right)$ was less than in $1992\left(530 \mathrm{~g} \mathrm{~kg}^{-1}\right)$. Regrowth was sampled in 1991 after killing frosts. In 1992, subfreezing temperatures had not yet occurred, and as a result, vegetation had not completely senesced when regrowth was sampled. Thus, differences between regrowth IVDMD in 1991 and 1992 may have been due to differences in amount of senescent plant material in forage samples.

\section{SUMMARY}

Genotype $x$ environment interactions were found to be important for forage yield and biofuel traits of elite switchgrass populations in seeded sward trials. These interactions led to a failure to detect significant differences at the 0.05 level of probability among populations for forage yield and holocellulose yield at heading when data were analyzed across years and locations. However, significant differences existed among populations at $P \approx$ 0.07 and $P \approx 0.11$, respectively, for these traits. Switchgrass stands will normally remain in production for periods of 10 to more than $20 \mathrm{yr}$ and failure to plant a high-yielding cultivar may cost a producer substantially during the life of the stand. Production costs for different switchgrass populations are essentially the same. Consequently, we think the risk of declaring significant differences between cultivars for forage yield when no differences exist (Type 1 error; Steele and Torrie, 1960) may be of less concern to producers than failure to declare significant differences between cultivars when such differences exist (Type 2 error). Based on these premises, use of probability levels of 0.10 or 0.15 is valid in declaring significant differences between switchgrass populations for forage yield and holocellulose yield.

Currently, the highest yielding populations adapted to the midwestern states for both forage and holocellulose yield are the cultivar Cave-in-Rock, its derived population, and some of the Nebraska populations. Most switchgrass populations were capable of producing large holocellulose yields at heading. Single location, multiple year testing in sward plots for switchgrass IVDMD at a vegetative growth stage should be adequate. The populations Ey $\times$ FF High IVDMD Cycle 3, Ey $\times$ FF High IVDMD Cycle 3 WS, and Trailblazer Pasture Clones ranked high for IVDMD at heading, demonstrating stability of genetic improvements in IVDMD across environments. In the midwest, switchgrass regrowth probably will not be harvested for hay or perhaps biofuel feedstock because of low forage yield following a previous harvest. Developing switchgrass populations broadly adapted to the midwest will likely require evaluating advanced breeding strains in sward trials at multiple locations and for multiple years.

\section{REFERENCES}

Bransby, D.I., S.E. Sladden, and D.D. Kee. 1990. Selection and improvement of herbaceous energy crops for the southeastern USA. Final Report. Oak Ridge National Laboratory, Oak Ridge, TN.

Cherney, J.H., K.D. Johnson, J.J. Volenec, E.J. Kladivko, and D.K. Greene. 1990. Evaluation of potential herbaceous energy crops on marginal croplands: I) Agronomic potential. Final Report. Oak Ridge National Laboratory, Oak Ridge, TN.

Eberhart, S.A., and L.C. Newell. 1959. Variation in domestic collections of switchgrass, Panicum virgatum L. Agron. J. 51:613-616.

Gabrielsen, B.C., K.P. Vogel, B.E. Anderson, and J.K. Ward. 1990. Alkali-labile cell-wall phenolics and forage quality in switchgrasses selected for differing digestibility. Crop Sci. 30:1313-1320.

Godshalk, E.B., J.C. Burns, and D.H. Timothy. 1986. Selection for in vitro dry matter disappearance in switchgrass regrowth. Crop Sci. 26:943-947.

Godshalk, E.B., W.F. McClure, J.C. Burns, D.H. Timothy, and D.S. Fisher, 1988a. Heritability of cell wall carbohydrates in switchgrass. Crop Sci. 28:736-742.

Godshalk, E.B., D.H. Timothy, and J.C. Burns. 1988b. Effectiveness of index selection for switchgrass forage yield and quality. Crop Sci. 28:825-830.

Hicks, C.R. 1973. Nested and nested factorial analysis. p. 227-251. In Fundamental concepts in the design of experiments. Holt, Rinehart, and Winston Co., New York.

Hopkins, A.A. 1993. Genetic variation among switchgrasses for agronomic, forage quality, and biofuel traits. Ph.D. diss. Univ. of Nebraska, Lincoln (Diss. Abstr. 1307730)

Hopkins, A.A, K.P. Vogel, and K.J. Moore. 1993. Predicted and realized gain from selection for in vitro dry matter digestibility and forage yield in switchgrass. Crop Sci. 33:253-258.

Hopkins, A.A., K.P. Vogel, K.J. Moore, K.D. Johnson, and I.T Carlson. 1995. Genotypic variability and genotype $\times$ environment interactions among switchgrass accessions in the midwestern USA. Crop Sci. 35:(in press). 
Jung, G.A., J.L. Griffin, R.E. Kocher, J.A. Shaffer, and C.F. Gross. 1985. Performance of switchgrass and bluestem cultivars mixed with cool-season species. Agron. J. 77:846-850.

Jung, G.A., J.A. Shaffer, and C.A. Fairbairn. 1988. Responses of four switchgrass cultivars to ammonium sulfate and urea in southeastern Pennsylvania. p. 171-175. In Proc. Forage and Grassl. Congress. Baton Rouge, LA. 11-12 Apr. 1988. Am. Forage Grassl. Council, Georgetown, TX.

Lynd, L.R., J.H. Cushman, R.J. Nichols, and C.E. Wyman. 1991. Fuel ethanol from cellulosic biomass. Science (Washington, DC) 251:1318-1323.

Marten, G.C. , and R.F Barnes. 1980. Prediction of energy digestibility of forages with in vitro rumen fermentation and fungal enzyme systems. p. 61-71. In W.J. Pigden et al. (ed.) Standardization of analytical methodology for feeds. Rep. IDRC-134e, International Development Centre, Ottawa, Canada.

Moore, K.J., L.E. Moser, K.P. Vogel, S.S. Waller, B.E. Johnson, and J.F. Pedersen. 1991. Describing and quantifying growth stages of perennial forage grasses. Agron. J. 83:1073-1077.

Neter, J., W. Wasserman, and M.H. Kutner (ed.). 1985. Applied linear statistical models. 2nd ed. Richard D. Irwin, Inc., Homewood, IL.

Newell, L.C. 1968. Registration of 'Pathfinder' switchgrass. Crop Sci. 8:516.

Parrish, D.J., D.D. Wolf, W.L. Daniels, D.H. Vaughan, and J.S. Cundiff. 1990. Perennial species for optimal production of herbaceous biomass in the Piedmont. Final Report. Oak Ridge National
Laboratory, Oak Ridge, TN.

SAS Institute. 1990. SAS user's guide: Statistics. Version 6. 4th ed SAS Inst., Cary, NC.

Satterthwaite, F.E. 1946. An approximate distribution of estimates of variance components. Biometrics 2:110-114.

Steele, R.G.D., and J.H. Torrie. 1960. Principles and procedures of statistics. McGraw-Hill Book Company, Inc., New York.

Stubbendieck, J., S.L. Hatch, and C.H. Butterfield. 1992. North American range plants. 4th ed. University of Nebraska Press, Lincoln, NE.

Twidwell, E.K., K.D. Johnson, J.H. Cherney, and J.J. Volenec. 1988. Forage quality and digestion kinetics of switchgrass herbage and morphological components. Crop Sci. 28:778-782.

Van Soest, P.J., and J.B. Robertson. 1980. Sequential analysis for evaluation of fibrous feeds. p. 49-60. In W.J. Pigden et al. (ed.) Standardization of analytical methodology for feeds. Rep. IDRC134e, International Development Centre, Ottawa, Canada.

Vogel, K.P., R. Britton, H.J. Gorz, and F.A. Haskins. 1984. In vitro and in vivo analyses of hays of switchgrass strains selected for high and low in vitro dry matter digestibility. Crop Sci. 24: 977-980.

Vogel, K.P, F.A. Haskins, H.J. Gorz, B.A. Anderson, and J.K. Ward. 1991. Registration of 'Trailblazer' switchgrass. Crop Sci. $31: 1388$.

Zeiders, K.E. 1984. Helminthosporium spot blotch of switchgrass in Pennsylvania. Plant Dis. 68:120-122. 